\title{
The case for a visualised economic sociology of legal development
}

\section{Amanda Perry-Kessaris ${ }^{1}$}

Winner of the 2015 Socio-Legal Studies Association Article Prize

Article published in Current Legal Problems (2014)

\begin{abstract}
Legal development work suffers from a general lack of inter-disciplinarity and from the associated dominance of economics. A more sociologically informed meta-framework, such as that offered by the emergent field of economic sociology of law, is required. But if it is to be robust, widely applicable and open to challenge, such an econo-socio-legal approach to development must be accessible across disciplines; and among academic, practitioner and public audiences. The reach of such a new approach could be radically improved using graphic design techniques such as typography and information design.
\end{abstract}

\section{A current legal problem}

'If you want a golden rule that will fit everything', proclaimed designer-writer-activist William Morris, 'this is it: Have nothing in your houses that you do not know to be useful or believe to be beautiful.'2 In delivering this advice Morris clearly had in mind those fortunates whose house is their castle. I want to push this a post-colonial step further

1 University of Kent, a.perry-kessaris@kent.ac.uk. I am indebted to members of the Economic Sociology of Law reading group at SOAS 2011-2013 for their intellectual camaraderie. For inducting me in the world of graphic design, thanks to Tony Pritchard and Ben Richards at London College of Communication, and to Kent Law School and SOAS for funding. For comments thanks to Kate Bedford, Fred Block, Roger Cotterrell, Tom Ginsburg, Linn Hammergren, Chandra Lekha Sriram and Brian Tamanaha.

2 William Morris, 'The Beauty of Life' in a lecture before the Birmingham Society of Arts and School of Design (19 February 1880), later published in Hopes and Fears for Art: Five Lectures Delivered in Birmingham, London, and Nottingham, 1878-1881 (Ellis and White 1992) Chapter 3. Available via the Gutenberg Project: http://www.gutenberg.org/ebooks/3773 
and urge that we cause not to be placed in the houses of others the potentially or actually un-useful or un-beautiful.

The current legal problem that I wish to confront is that 'law and development' is often neither useful nor beautiful. Legal development work focuses on the role of law--as a means, end, obstacle or irrelevance--in securing 'improvements' to human welfare; in particular the welfare of those who are seen to have less; especially in poorer countries. ${ }^{3}$ An early example is Henry Maine's observation that 'progressive' societies move (and improve) from a 'primitive' emphasis on 'status' or social structure, towards a 'modern' emphasis on 'contract' or agreements between individuals. ${ }^{4}$ That thinking was expressed specifically with a view to justifying and buttressing contemporary colonial practice. In post-colonial times, legal, economic and political thinking have twice more been sufficiently 'aligned' to produce relatively consistent justifications for such applied law and development: first when law was seen as a 'tool' for the 'developmental state' in the 1960s and 1970s, thereafter in the 1980s and 1990s when law came instead to be seen as a tool for the market and 'a shield against undesirable state intervention."5 In 2006, David Trubek and Alvaro Santos pointed to the beginnings of a (postModernisation, post-neoliberalism) 'third moment' in law and development among both academics and practitioners, defined by: 'the new attention to the limits of markets, the effort to define development as freedom not just growth, the stress on the local, the interest in participation, and the focus on poverty reduction.' This Third Moment was, they argued, 'more unsettled than the prior two periods of orthodoxy', with 'some aspects' remaining 'contested'.6 So it remains. Even definitions of legal development

3 For an overview see Michael Trebilcock and Mariana Moto Prado, What Makes Poor Countries Poor?: Institutional Determinants of Development (Edward Elgar 2011). $4 \quad$ Henry Sumner Maine, Ancient Law (1861) Chapter 5. See further Ritu Birla, 'Maine (and Weber) Against the Grain: Towards a postcolonial genealogy of the corporate person' in Diamond Ashiagbor, Prabha Kotiswaran and Amanda PerryKessaris (eds), Towards an Economic Sociology of Law (Wiley-Blackwell 2013) p. 104. Another, more famous, example is Maine's fellow evolutionary social theorist, Karl Marx. 5 David Trubek and Alvaro Santos, 'Introduction' in David Trubek and Alvaro Santos (eds.) The New Law and Economic Development (CUP 2006).

$6 \quad$ Ibid pp. 7 and 8. See also Dani Rodrik, 'Goodbye Washington Consensus, hello Washington Confusion? A review of the World Bank's economic growth in the 1990s: learning from a decade of reform' (2006) 44:4 Journal of Economic Literature 973-87. 
vary widely.7 Furthermore, some would argue that, despite decades of 'well-understood' failure in the field, the lessons of those failures are never truly 'integrated into our understanding', so that both academics and practitioners risk 'standing in much the same place a generation hence.'8 That place is, intellectually and practically, something of a mess.

One reason, argues Brian Tamanaha, why failures in legal development work so rarely translate into lessons is that there is no real, inter-connected, field of law and development. On the supply side, law and development is not a field, merely 'an agglomeration of projects advanced by motivated actors and supported by external funding.' ${ }^{\prime}$ On the demand side '[e]ligibility for law and development is defined in negative terms: any country not admitted to the advanced capitalist club is a candidate.' So little attention is paid to identifying among recipient countries 'shared qualities upon which to build insights.' ${ }^{10}$ To bridge both divides, Tamanaha invites us instead to think in terms of 'legal development'. Unlike 'law and development' or 'rule of law' work, legal development happens everywhere, all the time. In richer countries we call it government, planning, social policy and so on. While there are many practical discontinuities between rich and poor countries, close attention ought to be paid to identifying intellectual continuities-problems in respect of which intellectual resources can be pooled.

This article proposes that an economic sociology of legal development might offer a meta-framework within which such pooled resources might productively be organised.

$7 \quad$ See for example the Law and Development Review http://www.degruyter.com/view/j/ldr/('development aspects of international and domestic legal orders') accessed 22 March 2013; Law and Development Partnership http://www.lawdevelopment.com (justice and security, private sector development: governance and institutional development; and regional economic integration); and World Bank Law, Justice and Development topic page http://go.worldbank.org/YAUOR8VO20 ('how legal innovation and empowerment can contribute to national or international development') all accessed 22 March 2013.

$8 \quad$ Brian Z. Tamanaha, 'The primacy of society and the failures of law and development' [2011] 44 Cornell International Law Journal 209, p. 209.

$9 \quad$ Ibid p. 220.

$10 \quad$ Ibid p. 222. 
The first section explores the legal development work of the World Bank. The focus is on the Bank because it is a leading player across all, including legal, development work; and because it is dominated by economics, but aspires to interdisciplinarity. As such it illustrates the enormous constraints faced by practitioners, not least in terms of institutional structure, in connecting up their approaches. By contrast, academics have no excuse for failing to try. Indeed, one of the most valuable roles that academics might perform is to go beyond a critical enumeration of the errors and limitations of practitioners' ways, and to focus on helping practitioners to rethink those ways. Economic sociology of law appears to offer a unique meta-framework through which to systematically attempt such a rethinking (Section 2). The article concludes with the proposition that if communicated in visual form, such an econo-socio-legal approach might just prove to be transformative (Section 3).

\section{Comprehensive disconnectedness}

In 1998, the World Bank, a leader among the many legal development players, ${ }^{11}$ announced that henceforth its activities would be 'governed' by the Comprehensive Development Framework, which promotes approaches that are results-orientated, country-owned and led, long-term and holistic. ${ }^{12}$ Most thinkers and practitioners have, at least nominally, subscribed to the Framework since its launch. It is hard not to, for this is one ostensibly capacious and cuddly call to arms.

The term 'holistic' was intended to convey that 'all elements affecting a country's development (and the attendant investment options) should be put on the table, sideby-side, and given an equal chance for consideration' (original emphasis). Those elements were to include the macro-economic (stabilization, structural adjustment); the micro-economic (such as growth and productivity of agriculture and industry); and meso-level issues, including the 'institutional' (such as governmental, legal, and financial systems), the 'human or social' (such as education and health services)', and the 'physical' (such as water, infrastructure and environment). Much is made of the fact that this enables 'priorities' to be 'set', and 'hard choices...made against a real budget

11 For a review of the global players see IDLO, IDLO Legal and Judicial Development Assistance Global Report (2010). Available at

http://www.idlo.int/DOCNews/LJ\%20Annual\%20report\%20with\%20Annexes.pdf.

12 World Bank 'Comprehensive Development Framework' Website

http://go.worldbank.org/N2NDBE5QL0 accessed 22 March 2013. 
constraint, and linked to a multi-year expenditure framework.'13 Realistic budgeting is an absolutely crucial skill, especially for those who have limited resources. But this is very partial sort of holism. In taking a holistic approach to medicine the point is to approach a person as a psychological-physical-spiritual whole; not to facilitate a choice between different 'elements' played off against each other: the left kidney against self esteem, a sense of smell versus a belief in an afterlife. Likewise, the point of 'comprehensive' development ought to be that these institutional, human/social and physical 'elements affecting ... development' cannot but be 'side-by-side' on any 'table'; for they are always fully intertwined.

A more promising, and legally attuned, version of holistic development was offered by Amartya Sen who had been arguing for several decades that development lies not in mere economic growth, but in the enhancement of human capabilities. ${ }^{14}$ Asked to comment on the role of law in comprehensive development at a 2000 World Bank Legal Department conference Sen proposed that legal development is-together with economic, social and political development-an interdependent, mutually reinforcing, component of comprehensive capability-enhancing development. So, effective law is facilitative of other development goals, such as economic growth; but it is also a development goal in itself, such that 'even if legal development were not to contribute one iota to economic development', it would still be a crucial part of the development process. ${ }^{15}$ Sen accordingly advised the Bank to 'investigate the interconnections between law and all other spheres of social life', for actions taken in respect of each aspect of development 'must all hang together, or most assuredly [they] shall all hang

13 Operations Evaluation Department, Toward Country-led Development: a MultiPartner Evaluation of the Comprehensive Development Framework (World Bank 2003), p. 8. 14 See Amartya Sen, 'Development as Capability Expansion' (1989) 19 Journal of Development Planning 41-58 and Development as Freedom (OUP 2001). See also Julio Faundez 'Rule of Law or Washington Consensus: the evolution of the World Bank's approach to legal and judicial reform' in Amanda Perry-Kessaris (ed.) Law in Pursuit of Development: principles into practice? (Routledge, 2010) Chapter 11.

15 Brian Z. Tamanaha 'The primacy of society and the failures of law and development' [2011] 44 Cornell International Law Journal 209, pp. 214 and 222-4. 
separately'.16 On the face of it, the point was well taken. In 2009, the World Bank Legal Vice Presidency could be found dutifully stating that: 'A well-functioning legal and judicial system is critical not only as an end in itself, but also as a means of facilitating the achievement of other development objectives.' 17 However, that sentiment has too rarely been manifested in practice, thanks to two interrelated factors: a lack of interdisciplinarity and the dominance of economics.

The 'near-monopoly' of economics within the World Bank is indisputable and no secret. It was noted, for example, by Vijayendra Rao and Michael Woolcock, then respectively lead economist and senior social scientist in the World Bank Development Economics Research Group in 2007. Economists have, they wrote, 'made a lot of progress' towards understanding 'key issues like institutions, collective action, and politics'. But every discipline is 'limited', and economics is especially so in its ability to understand 'issues outside its domain'. Therefore, economists should leave the 'areas of social, cultural and political action' to 'the other social sciences who specialize in these topics'.18 The roux of the neoliberal economic secret sauce, and many of its limitations, lies in three assumptions: ${ }^{19}$ individuals always seek to 'maximise' (so, for example, they are prone to identifying and promoting efficiency); markets 'coordinate the actions of different participants - individuals, firms, even nations - so that their behaviour becomes mutually consistent' (and therefore, among other things, efficient); actors know what they want (which, among other things means that they are well placed to

16 Amartya Sen 'What is the role of judicial reform in the development process?' Speech delivered at a Wold Bank Conference on Comprehensive Legal and Judicial Development (June 5th,2000), p. 10. Available at < http://siteresources.worldbank.org/INTLAWJUSTINST/Resources/legalandjudicial.pdf Accessed 22 March 2013.

17 World Bank Initiatives in Justice Reform 2009 (World Bank 2009), p. 2.

18 Vijayendra Rao and Michael Woolcock, 'Disciplinary monopolies in development research: A response to the research evaluation process' [2007] 13 Global Governance: A Review of Multilateralism and International Organizations 479, pp. 479-80.

19 Gary Becker, The Economic Approach to Human Behavior (University of Chicago Press 1976), p.5. 
maximise their own welfare and, consequently, efficiency). ${ }^{20}$ There is vigorous debate, within economics and beyond, about the limits of these assumptions. For example, behavioural economists have in recent decades encouraged us to be aware of, and seek to co-opt, those human tendencies that neoclassical economics would dismiss as 'irrational'.21 At the same time, the last decade has seen rising calls for evidence-based (as opposed to assumption-based) development programmes. Abhijit Banerjee and Esther Duflo have pioneered the use of randomised controlled trials (RCTs) in order to liberate development work from 'ideology, ignorance and inertia'.22 But economics remains a remarkably narrow, fundamentally a-social, abstract, obsessively quantitative discipline. ${ }^{23}$ It is also imperial: the 'institutional turn in economics' has triggered 'a convergence' in the approaches of 'new institutional economics and long-standing jurisprudential traditions in legal realism, law and development, and law and society'.24

20 Note that these assumptions defy the 'approaches' terminology set out below, in that they merge the analytical and the empirical. They are unabashed concept-facts.

21 See George A. Akerlof and Robert J. Shiller, Animal Spirits: How human psychology drives the economy and why it matters for global capitalism (Princeton 2009); and Richard Thaler and Cass Sunstein, Nudge: Improving decisions about health, wealth and happiness (Penguin, 2009). The nudge approach has made significant inroads in the UK public sector via the bijou (recently part-privatised) Behavioural Insights Team or 'Nudge Unit' of the Cabinet Office.

22 For an introduction to RCTs, including multiple examples, see Abhijit V. Banerjee and Esther Duflo Poor Economics: Barefoot hedge-fund managers, DIY doctors and the surprising truth about life on less than $\$ 1$ a day (Penguin 2010). Details of a leading RCT methodology can be found at the Abdul Latif Jameel Poverty Action Lab http://www.povertyactionlab.org/methodology. Their book won the FT/Goldman Sachs business book of the year.

23 See generally Ben Fine and Dimitris Milonakis, From Economics Imperialism to Freakonomics (Routledge 2009).

24 Terrence C. Halliday, 'Legal Yardsticks: International Financial Institutions as Diagnosticians and Designers of the Laws of Nations (September 9, 2011). Center on Law and Globalization Research Paper No. 11-08. Available at SSRN: http://ssrn.com/abstract=1928829.p. p. 35. Accessed 22 March 2013. See also Galit A Sarfaty, 'Measuring Justice: Internal Conflict over the World Bank's Empirical Approach 
The most notable movement (analytical, empirical and normative) has been by law, and towards a distinctively neoclassical economic approach. ${ }^{25}$

Orthodox economic approaches to legal development seem to prosper not only because international financial institutions are 'the natural territory of economists and finance specialists', ${ }^{26}$ but also because there is no widely understood, broadly accepted, coproduced interdisciplinary alternative to them. A genuinely comprehensive approach to development, in which all aspects of human welfare are valued both independently and collectively, requires inter-disciplinarity. Teams of experts from a range of disciplines would work 'together, perhaps synergistically, but certainly harmoniously' and would 'share in the pride of their mutual accomplishments'. Inter-disciplinarity is quite different from mere multi-disciplinarity, in which, to quote a child protection specialist, 'the reality is that ... group A fail[s] to communicate with group B' and, although they are 'working towards the same goal', these two groups are at the same time 'in competition-for resources or recognition.' ${ }^{27}$ So what is the World Bank approach? It 'brings a multidisciplinary approach to its justice work, combining expertise from lawyers, economists, social scientists, financial management experts. ${ }^{28} \mathrm{Oh}$ dear. This is no inconsequential slip of the tongue. A 2003 multi-stakeholder scrutiny of the Framework noted that progress on comprehensive development is impeded by a lack of 'internal structures that encourage cross-sectoral dialogue or easy integration of multisector interventions', together with cultures of 'silo thinking' and 'competition', all of which are to be found within and among most donor agencies and recipient

to Human Rights', in Kamari Clarke and Mark Goodale (eds), Mirrors of Justice: Law and Power in the Post-Cold War Era. (Cambridge University Press 2009), 131.

25 See further Amanda Perry-Kessaris, 'Prepare your indicators: economics imperialism on the shores of law and development' [2011] 7:4 International Journal of Law in Context 401.

26 Terrence C. Halliday, 'Legal Yardsticks: International Financial Institutions as Diagnosticians and Designers of the Laws of Nations' (September 9, 2011). Center on Law and Globalization Research Paper No. 11-08. Available at SSRN:

http://ssrn.com/abstract=1928829,pp. 31-2.

27 Ivan B. Pless, “'Interdisciplinary” and "multidisciplinary” are not synonymous' (1995) Injury Prevention 165, 165.

$28 \quad$ World Bank, Initiatives in Justice Reform 2009 (World Bank 2009), 1-2. 
governments. ${ }^{29}$ Until recently, legal work was multi-siloed, operating across a range of groups, ${ }^{30}$ often on parallel, even divergent, tracks. ${ }^{31}$ The Bank has attempted to address this and other structural problems in a number of ways. First, as of summer 2014, it has brought almost all law and development work together under the umbrella of the Governance Global Practice Group-the largest of 14 such Groups. An important and telling exception is the ultra-neoliberal, highly influential, Doing Business project that aims to reduce business regulation through market forces. It retains its private dominion, bounded by a separate internet domain name. ${ }^{32}$ The implications of that

29 Operations Evaluation Department, Toward Country-led Development: a MultiPartner Evaluation of the Comprehensive Development Framework (World Bank 2003) xx, 19 and 59. Likewise, the Bank's Poverty Social Impact Analysis (PSIA) programme of work, which aims to identify the distributional impacts of policies, appears to undermined by its segmented (multi-disciplinary) approach. A PSIA 'toolkit' notes over 20 different methods of measuring of 'impact'. The effect, in terms of quantity and diversity, is paralysing. See Francois Bourguignon and Luiz A. Pereira da Silva, The impact of economic policies on poverty and income distribution: evaluation techniques and tools (World Bank 2003). A 2010 evaluation was triggered in part by complaints from Oxfam and others was critical of the quality and effectiveness of the programme: Independent Evaluation Group, Analyzing the Effects of Policy Reforms on the Poor: An Evaluation of the Effectiveness of World Bank Support to Poverty and Social Impact Analyses (World Bank 2010) xi and 35-40. See also Jeremy Holland, Tools for institutional, political, and social analysis of policy reform: a sourcebook for development practitioners (World Bank 2007).

30 Namely: the Poverty Reduction and Economic Management Network, the World Bank Institute, Private Sector Development, Environmentally and Socially Sustainable Development, and the Legal Vice-Presidency. See World Bank, 'Introduction to World Bank Law and Justice Reform Projects http://go.worldbank.org/UXYGDB43Z0 accessed 22 March 2013.

31 Alvaro Santos, "The World Bank's Uses of the "Rule of Law" Promise in Economic Development', in David M. Trubek, and Alvaro Santos (eds), The New Law and Economic Development: A Critical Appraisal (Cambridge University Press 2006) 253.

32 See Amanda Perry-Kessaris, 'Prepare your indicators: economics imperialism on the shores of law and development' [2011] 7:4 International Journal of Law in Context 401. 
continuing division split remain to be seen. Second, the Bank has established a Global Forum on Law Justice and Development in order to 'generate innovative legal solutions to development challenges' ${ }^{33}$ The audio recordings of meetings make salutary listening: the number of institutions, topics and perspectives is vast. It is an enormous task, and it still takes place in an economic meta-silo.

There is room for optimism within the Bank. Its Justice for the Poor (J4P) programme, co-founded by Michael Woolcock, shows a keen sensitivity to, and interest in, legal development as an interconnected part of human (including economic) development. It is targeted towards 'outcomes' rather than 'predetermined institutional structures'. ${ }^{34}$ In part because its client countries are often sites of legal pluralism, J4P consciously seeks to take a comprehensive approach to the legal system 'including state, non-state, and hybrid systems' ${ }^{35}$ One of the aims of the programme is to 'enhance the effectiveness of other development efforts by supporting them to address the justice and conflict management related aspects of their work' (my emphasis). ${ }^{36}$ This is precisely the collaborative space in which comprehensive legal development efforts ought to reside. In keeping with the incremental, iterative, evidence-based and long-term tone of the J4P approach, the programme has only been active in a limited range of countries, albeit

33 World Bank, New Directions in Justice Reform: A companion piece to the updated strategy and implementation plan on strengthening governance, tackling corruption (World Bank 2012).

34 This echoes the much earlier observation of Andrew Stone, Brian Levy and Ricardo Paredes that 'institutions matter economically in the actual costs (and benefits) they create for businesses, not in their compliance with ideal forms' in 'Public institutions and private transactions : the legal and regulatory environment for business transactions in Brazil and Chile' Policy Research Working Papers (World Bank 1992, p. 1).

35 World Bank, 'Justice for the Poor' http://siteresources.worldbank.org/INTJUSFORPOOR/Resources/JusticeforthePoorTwoPager.pdf. See further Brian Z. Tamanaha, Caroline Sage and Michael Woolcock (eds), Legal Pluralism and Development: Scholars and practitioners in dialogue (CUP 2012).

36 See World Bank 'Justice For the Poor: Objectives' http://go.worldbank.org/027JLLWW30Accessed 22 March 2013. 
including some larger ones such as Indonesia and Nigeria. So there remains plenty of scope for consistently louder, thinner and more orthodox economic approaches, such as that adopted by the Doing Business programme, to dominate within the Bank. ${ }^{37}$ In this delicate and shifting context, how might academics contribute to the nurturing of collaborative, connected, interdisciplinary legal development work?

\section{An economic sociology of legal development?}

If academics are to generate useful insights into legal development practice, they must begin to offer intellectually connected approaches. Instead, academics tend to come at the field using a veritable fiesta of semi-to-wholly incompatible approaches, each aligned with specific disciplines (such as law, economics, politics) or trans-disciplinary theories (such as feminism, Marxism or systems theory). Too often they fail to refer systematically and productively to each other. ${ }^{38}$ So it is hard to make integrated sense of it all, to retain thoughts, to follow threads. All of this is undermines the depth and solidity of the resulting scholarship, as well as its practical impact. It is no great wonder that practitioners rarely listen.

Part of the underlying cause of this intellectual disconnectedness is that we cling so tightly to our 'legal', our 'economic' and our 'social'. Crucially, as Viviana Zelizer has observed, we tend to cleave to one of three equally unrealistic approaches to thinking about economic processes. First, a 'separate spheres' approach 'posits two distinct arenas of social life, one oriented toward rational effectiveness', 'the other toward sentiment and solidarity'. This is the approach exhibited in the Comprehensive Development Framework version of 'holistic'. Second, a 'hostile worlds' approach goes further down the same path, suggesting that if the 'two spheres' come to 'intersect' too closely, 'mutual contamination' - by rationality and efficiency of sentiment and solidarity, and vice-versa-will ensue. As a consequence, 'non-economic', including legal, accounts of development are often as under-socialised and formalistic as the economic accounts. Alternatively they are over-socialised and unable and/or unwilling

37 World Bank 'Justice for the Poor: Approach and activities' http://go.worldbank.org/NVC7Y7MXO0 and 'Justice for the Poor: Objectives' http://go.worldbank.org/027JLLWW30 accessed 22 March 2013.

$38 \quad$ For instances in which lawyers and economists have studiously failed to pool their resources on the topic of law and economic growth see Michael Faure and Jan Smits (eds), Does Law Matter? On law and economic growth (Intersentia 2011), part I. 
to accommodate the economic, even as they pay special attention to the role played by 'economic' activities (production, distribution, consumption and transfer), and associated ways of thinking, in securing, perverting or preventing legal development. Clearly any approach to legal development, even one that is explicitly anti-orthodox economics, must communicate with (rather than merely displace or shun) economic concepts and relationships, facts and methods, values and interests.

Third, 'nothing but' approaches offer 'an array' of dramatic 'characterizations' of all econo-socio-(and legal) activities as, for example, 'nothing but rationally organized markets, nothing but power, nothing but culture. ${ }^{39}$ This is the approach exhibited in the production and deployment of indicators (by which legal systems are benchmarked as if commodities competing for the attentions of foreign investors), which has caused a large-scale diversion of attention away from potentially productive activities, and which persist despite the desire of many lawyers within the institutions that produce them 'to see ... the steamroller break down'.40 Each of these three approaches turns its back to the reality that we live 'connected lives'41

Reading left to right, Figure 1 suggests that we all too often stand with our backs to each other, preaching towards our disciplinary comfort zones. Real life is an econo-sociolegal tangle, so we should turn around: pool the concepts, facts and values that are characteristic of law, economics and sociology to produce a connected, econo-sociolegal, approach. We might then think, for example, of production and consumption not

39 Vivianna A. Zelizer, Economic Lives: how cultural shapes the economy (Princeton University Press 2011), 5-6.

40 Terrence C. Halliday, 'Legal Yardsticks: International Financial Institutions as Diagnosticians and Designers of the Laws of Nations (September 9, 2011). Center on Law and Globalization Research Paper No. 11-08, 43. Available at SSRN: http://ssrn.com/abstract=1928829. Accessed 22 March 2013. See also Yves Dezalay and Bryant G. Garth (eds), Lawyers and the Construction of Transnational Justice (Routledge, 2012) and Lawyers and the Rule of Law in an Era of Globalization (Routledge, 2011); and Amanda Perry-Kessaris, 'Prepare your indicators: economics imperialism on the shores of law and development' [2011] 7:4 International Journal of Law in Context 401.

41 Vivianna A. Zelizer, Economic Lives: how cultural shapes the economy (Princeton University Press 2011) 5-6. 
as 'the economy', but as social activities with econo-legal dimensions; of laws and institutions not as 'the legal' but as econo-social constructs; and of actions and interactions not as 'the social' but as econo-legally significant aspects of social life.

[Figure 1 about here]

Connectedness is what the emergent scholarship of economic sociology of law (ESL) does best: it breaks with the convention of approaching different aspects of human life as categories, performed in isolation, and by entirely separate people. A sociological lens, specifically calibrated to avoid 'over-' and 'under-socialised' accounts, 42 is applied to the economic and legal, reinterpreting them as social phenomena-that is, as actions, interactions, regimes and rationalities which are created and performed by interconnected, multi-tasking human beings, acting individualistically and communally. The black-box of the economy is opened to reveal production, distribution, exchange and consumption as primarily social activities. Rules and institutions are unleashed from the legal, becoming more alive, and readily appreciable, as social actions and constructs. Organised along the existing threads of social life, this is an inherently interconnected approach: the economic and the legal, but also the micro and macro, local and transnational, empirical and abstract, are all placed on the same analytical page; and insights into how law can support productive economic activity flow organically to all. At the heart of this 'connected lives perspective' is a celebration of 'bridging'43_of disciplines, theories, methodologies and perspectives. ${ }^{44}$

Claims to be working in the realm of economic sociology of law demand, in the words of Fred Block, 'considerable humility'. For 'legal thinkers have been struggling with the empirical realities of economic activity for many years, and the ideas of important sociologists have been part of the background intellectual culture of legal thinkers for

42 Mark Granovetter, 'Economic Action and Social Structure: the Problem of Embeddedness' (1985) 91 American Journal of Sociology 481.

43 Vivianna A. Zelizer, Economic Lives: how culture shapes the economy (Princeton University Press 2011), 357 and 359.

$44 \quad$ See further Julie Thompson Klein, Crossing Boundaries: Knowledge, disciplinarities and interdisciplinarities (University Press of Virginia 1996) 4-5. 
three or four generations.' 45 Two Karls (Marx and Polanyi) and a Max (Weber), to name but a few. ${ }^{46}$ Indeed economist Amartya Sen's version of comprehensive development echoed many decades of inter-disciplinary legal research through which the doctrinal approach to law, which is to examine the text of law, has been supplemented with sociologically-informed emphasises on the constitutive, recursive relations that exist between law and its social context; and with critical approaches which emphasise the hidden subtext of law. Furthermore, an enormous range of work is in the sprit of ESL, covering issues from labour, social policy and gender; to regionalism, constitutionalism, the corporate form, high frequency trading, money, the construction of economic rationalities, micro-finance and law and development generally. ${ }^{47}$ Such work has not tended to focus specifically on the development context, despite its obvious applicability, and despite the substantial attention and resources devoted by policy makers to legal development work. So existing scholarship must be both excavated and repurposed, if economic sociology of law is to act as a meta-frame of reference through which to consolidate, reflect and act upon them. A number of others have begun that process, and this is not the place for a full review. 48 Instead, the following sections

45 Fred Block, 'Relational work and the law: Recapturing the Legal Realist critique of market fundamentalism' in Diamond Ashiagbor, Prabha Kotiswaran and Amanda Perry-Kessaris (eds) Towards an Economic Sociology of Law (Wiley-Blackwell 2013), 27. 46 For a brief history see Sabine Frerichs, 'From Credit to Crisis: Max Weber, Karl Polanyi, and the Other Side of the Coin' in Diamond Ashiagbor, Prabha Kotiswaran and Amanda Perry-Kessaris (eds) Towards an Economic Sociology of Law (Wiley-Blackwell 2013), 7.

47 See for example, Diamond Ashiagbor, Prabha Kotiswaran and Amanda PerryKessaris (eds), Towards an Economic Sociology of Law (Wiley-Blackwell 2013) and (2014) Northern Ireland Legal Quarterly Special Issue 'Continuing towards an economic sociology of law'.

48 See Richard Swedberg, 'The case for an economic sociology of law' (2003) 32 Theory and Society 1; Lauren B. Edelman and Robin Stryker, 'A Sociological Approach to Law and the Economy' in Neil J. Smelser and Richard Swedberg (eds)The Handbook of Economic Sociology (Princeton University Press 2005), 527-51; and Amanda PerryKessaris, 'Envisioning the econo-socio-legal' forthcoming in Annual Review of Law and Social Sciences 2015. 
gather together some key analytical, empirical and normative threads that run through econo-socio-legal approaches. ${ }^{49}$

\section{Analytical approach}

The analytical characteristics of an approach are to be found in the concepts and relationships through which it is organised. Economic sociology conceptualises both the 'legal' and the 'economic' as social phenomena that occur on all, interconnected, levels of social life: in the actions of individuals, their interactions with others, the regimes into which those interactions 'aggregate', and the rationalities that 'direct' them. ${ }^{50}$ The following paragraphs explore each level in turn. Always at the centre of the analysis are human beings: a focus that is entirely consistent with a comprehensive development agenda. And these humans are social, for, as Karl Marx put it: 'The human is being is in

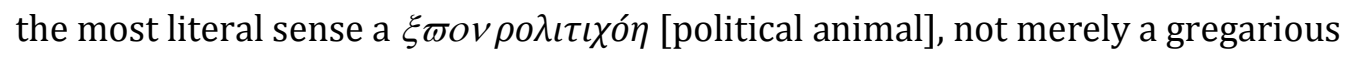
animal, but an animal which can individuate itself only in the midst of society'. ${ }^{51}$

[Figure 2 about here]

First, social actions centre on divergent values and interests. Figure 2 demonstrates one way to think about this is. Values and interests are illustrated by reference to the human body using Weber's typology of affective (heart), belief (head), traditional (foot) and instrumental (hand). This image reminds us that economic activities (production, distribution, consumption and transfer) are just one sub-type of instrumental social action connected, through multi-tasking human beings, with other forms of social action (instrumental and otherwise). For example, a woman might be at once pounding shea butter for sale to Body Shop International (hand), delighting in an inside joke told by her

49 This schema draws on Amanda Perry-Kessaris, 'What does it mean to take a socio-legal approach to international economic law?' in Amanda Perry-Kessaris (ed), Socio-Legal Approaches to International Economic Law: Text Context Subtext (Routledge 2013).

50 Sabine Frerichs, 'Re-embedding neo-liberal constitutionalism: a Polanyian case for the economic sociology of law' in Christian Joerges and Josef Falke (eds.) Karl Polanyi, Globalisation and the Potential of Law in Transnational Markets (Hart 2011), 68. My emphasis.

51 Karl Marx, Grundrisse: Foundations of the Critique of Political Economy (first published 1939, Martin Nicolaus tr., 2 ${ }^{\text {nd }}$ Peguin edn, 1993). 
dear friend (heart), telling an Ashanti cautionary tale (foot), and attributing her healthy constitution to the combined forces of evolution and God (belief).

Second, social interactions cover the full range of actions, and they occur at different intensities. Figure 2 shows two actors in four possible sets of interactions. The dominant motivation(s), or underlying values and interests, of their interactions is suggested by the part of the body to which lines connect. In only one example is the relation exclusively instrumental. In the other three examples the actors are connected by a more complex combination of values and interests. The intensity of their relationship is captured in the intensity of the line. Broken lines indicate ad hoc interactions. Solid lines indicate repeated interactions that are associated with a sense of belonging and trust. Here I am thinking of the actors as members of Roger Cotterrell's 'communal networks' - relatively stable interactions, grounded in mutual interpersonal trust and a sense of belonging; and of Viviana Zelizer's 'circuits of commerce'-boundaried interactions involving 'distinctive transfers' via 'shared media'.52 Importantly, 'the same people participate ...simultaneously' in different 'networks' or 'circuits', economic or otherwise. ${ }^{53}$ They are living 'connected lives' that defy 'separate spheres', 'hostile worlds' and 'nothing buts'. So for example, foreign investors, aid workers, government officials, project-affected-persons, legal professionals, are all likely to be engaged in multiple, sometimes overlapping and/or contradictory networks. ${ }^{54}$

Third, laws and other regimes are of sociological interest because they are social phenomena. They provide the regulatory and facilitative environments in which

\section{Roger Cotterrell, Law, Culture and Society: Legal ideas in the mirror of social} theory (Ashgate 2006), 162-3. Zelizer uses 'commerce' in 'old sense' of 'conversation, interchange, intercourse and mutual shaping': Vivianna A. Zelizer, Economic Lives: how culture shapes the economy (Princeton University Press 2011), 314-5.

53 Vivianna A. Zelizer, Economic Lives: how culture shapes the economy (Princeton University Press 2011), 316.

54 See also Terrence Halliday's sociological analysis of the use of legal system indicators ('legal yardsticks') both within and outside international financial institutions (IFIs) in Terrence C. Halliday, 'Legal Yardsticks: International Financial Institutions as Diagnosticians and Designers of the Laws of Nations (September 9, 2011). Center on Law and Globalization Research Paper No. 11-08, p. 43. Available at SSRN: http://ssrn.com/abstract=1928829. Accessed 22 March 2013. 
economic activity takes place..$^{55}$ Law is a means (or an obstacle) to improving human welfare when it triggers, facilitates or hinders (un)productive social action and interactions. It does this by expressing (or not) and coordinating (or not) the, often competing, values and interests that are central to different social actions; and by facilitating and encouraging (or not) participation in social life. ${ }^{56}$ Importantly, while law can support (or not) 'networks' or 'circuits', it cannot create them. In this context 'development' is about ensuring that law facilitates, or gets out of the way of, a greater range of relatively productive social actions. These actions may occur in the form of, but will not be limited to, 'markets'. Drawing on Sen, Tamanaha has observed that the 'connectedness of law' makes legal development absolutely central to human development: judicial institutions are key determinants of wellbeing because those legal institutions can facilitate or prevent econo-social improvements. At the same time, 'the connectedness of law' explains why much law and development programming, with its heavy emphasis on isolated and state-centric judicial reform, is so fundamentally hopeless: econo-social life can facilitate or prevent legal development. ${ }^{57}$ The connectedness of law is rooted in the connectedness of human beings-physically individual, always also socially connected. Chandra Lekha Sriram has made this point in relation to the use of criminal tribunals in societies affected by conflicts and atrocities, such as Sierra Leone and Kenya. Whether home-grown, internationally led or hybrid, such tribunals are expected to 'project important lessons to a society or a culture which is deemed to be damaged or lacking' a culture of, for example, respect for rule of law or human rights. But the institutions that are 'expected to deliver' these 'important

55 Lauren B. Edelman and Robin Stryker, 'A Sociological Approach to Law and the Economy' in Neil J. Smelser and Richard Swedberg (eds), The Handbook of Economic Sociology (Princeton University Press 2005), 535-40.

56 Roger Cotterrell, Law, Culture and Society: Legal ideas in the mirror of social theory (Ashgate 2006); as elaborated in Amanda Perry-Kessaris, Global Business, Local Law: The Indian legal system as a communal resource in foreign investment relations (Ashgate 2008).

57 Brian Z. Tamanaha, 'The primacy of society and the failures of law and development' [2011] 44 Cornell International Law Journal 209, 214 and 222-4. 
messages to local culture' are often 'driven by' local or foreign 'elites' and the resulting processes often 'do not easily connect with a significant portion of the population'. ${ }^{58}$ Fourth, rationalities are 'shared ways of apprehending the world'.59 They may be based in disciplines (economics, law, sociology etc.), organisations (bureaucracies, religious groups etc.) belief systems and so on. They are of socio-legal interest to the extent that they are constitutive of, and constituted by, legal phenomena-in particular the creation, use, abuse, avoidance and destruction of laws. ${ }^{60}$ In a dictatorship, legal development follows the rationalities of the dictator, in a democracy, some mash-up of the rationalities of 'the people'. 'Law and development' has too often been about following, and reflecting in regimes, the rationalities of those who fund programmes. Since the 1980s, that rationality has been neoliberal. When we take a sociologically informed approach, we see rationalities as manifested in real people interacting across the full spectrum of affective, belief, traditional and instrumental relationships. This reminds us that there can be no general rule about whether legal development ought to, or indeed can, follow and reflect existing rationalities, or try to shift them.

So an econo-socio-legal approach prompts organised reflection upon the rationalities, and associated regimes, that are characteristic of the 'law and development' industry. This means that it is a useful and beautiful way to understand 'law and development' practice-policy, personnel, programming, institutions and scholarship-as econosocio-legal phenomena.

58 Chandra Lekha Sriram, 'Tribunals, legacies, and local culture: Lessons from some African experiences with international criminal justice' (Käte Hamburger Centre for Advanced Study 'Law as Culture’ series forthcoming 2013). See also Gregory Massell, 'Law as an instrument of revolutionary change in a traditional milieu: The case of Soviet Central Asia' (1968) 2 Law and Society Review 179.

59 John S. Dryzek, The Politics of the Earth: Environmental discourses (OUP 2005), 9 and Part 3.

60 Lauren B. Edelman and Robin Stryker, 'A Sociological Approach to Law and the Economy' in Neil J. Smelser and Richard Swedberg (eds)The Handbook of Economic Sociology (Princeton University Press 2005), 540-42. See also Amanda Perry-Kessaris, 'Reading the story of law and embeddedness through a community lens: a Polanyimeets-Cotterrell economic sociology of law?' (2011) 62(4) Northern Ireland Legal Quarterly 401. 


\section{Empirical approach}

The 'empirical' characteristics of an approach are to be found in the facts and methods that are used to confirm, challenge or disprove the real-life existence of concepts and relationships. Sociology (unlike much of law, and of economics, with its concept-facts ${ }^{61}$ ) is distinguished by its commitment to the importance of such empirical confirmation. So an economic sociology of law necessitates a self-conscious emphasis on empirical manifestations of social (economic and legal) phenomena. ${ }^{62}$

Real life is best addressed using predominantly real life sources. 'Facts' ought to be collected from fieldwork, surveys, experiments and documentary research and subjected to both qualitative and quantitative methods of analysis. ${ }^{63}$ The Bank has been criticised from within for its excessive reliance on econometric analysis of survey data, which limits its ability to 'ask important questions about the social, cultural and political context within which development problems are embedded;' and causes it to 'miss important aspects of some critical economic issues', including the 'heterogeneity' of socalled 'informal' markets for labour, and the very existence 'marginal' markets for 'drugs, political favors, and sex'. Researchers cannot access these fields unless they have 'a strong degree of rapport with respondents' of the kind a questionnaire cannot cultivate.64 One example of a promising empirical intervention comes from Terrence Halliday and Bruce Carruthers' explicitly qualitative assessment of the post-Asian Financial Crisis creation, contestation and evolution of corporate bankruptcy norms. Through seven years of interviews with hundreds of informants, participating in negotiation meetings, and taking advantage of their observer status with a United

61 Deidre McCloskey, The Secret Sins of Economics Prickly Paradigm No. 4. (Prickly Paradigm Press 2002).

62 For a detailed demonstration of one version of this method see Antara Haldar, 'Law and development in crisis: an empirical challenge to the current theoretical frames' in (2014 forthcoming) Northern Ireland Legal Quarterly Special Issue on continuing towards an economic sociology of law.

63 Anthony Giddens, Sociology (Polity Press, 6 ${ }^{\text {th }}$ ed, 2009), Chapter 2.

64 Michael Bamberger, Vijayendra Rao and Michael Woolcock, 'Using mixed methods in monitoring and evaluation: experiences from international development' Policy Research Working Paper 5245 (World Bank 2010), 2. 
Nations commission, they 'open[ed] the black box in which global policy norms are debated and decided'. ${ }^{65}$

The dominance of quantitative data makes it forever worth emphasising that numbers are no more reliable than words. ${ }^{66}$ Even the basic gross domestic product (GDP) statistics that are foundational to so much of the work of organisations such as the World Bank, have in recent years been shown to be astonishingly unreliable. ${ }^{67}$ It is not too worrisome to have incorrect figures if you are interested tracing changes in those figures (e.g. economic growth); but it is catastrophic if you are interested in the size of the figure itself (e.g. actual GDP). These inaccuracies in GDP reside wherever there is informality, barter, geographical inaccessibility, dishonesty: in short everywhere. So that highly influential horde of econometric estimations which for example, claim positive relationships between GDP and legal institutions, 'are meaningless.' The main reason for their continuing dominance is, according to Jerven, the availability of data sets and

65 Terrence C. Halliday and Bruce G. Carruthers, Bankrupt: Global lawmaking ad systemic financial crisis (Stanford University Press, 2009).

66 It is also worth pausing to note that caution must be exercised even when constructing an empirical mixture, for quantitative methods favoured by economics tend to dominate. See for example Gary King, Robert O. Keohane and Sidney Verba, Designing Social Inquiry: Scientific Inference in Qualitative Research (Princeton University Press, 1994), outlining a qualitative approach to research based on the logic of quantitative approaches; and James Fearon and David Laitin, ('Integrating Qualitative and Quantitative Methods' in Oxford Handbook of Political Methodology (OUP 2010), which sets out the combination of statistical data-plus experiment-plus case study method that has become something of a standard among political scientists in the US. Thanks to Fiona Adamson for this point.

67 For example, Morten Jerven notes that Ghana's GDP figures were recalculated and found to be 'almost double the size of what they previously thought and previously published.' The country went from 'poor' (eligible for concessional lending) to 'middle income' (ineligible) in one corrective swoop: Morten Jerven, 'The relativity of poverty and income: How reliable are African economic statistics?' (2010) African Affairs 109:434, 77-96. 
computers, which make it so 'very easy to do research on the costs of economic development from your office'.68

Elsewhere, ostensibly quantitative methods are applied to fields that are entirely unsuited to measurement. For example, one influential working paper uses top-notch econometric methods to reach the startling conclusion that the absence of law is the cause of the ultimate state of lawlessness: civil war. Set aside the circularity and focus on the approach:

The authors set up a model in which institutions are endogenous and colonial origins affect civil wars through their legacy on institutions. The results indicate that institutions, proxied by the protection of property rights, rule of law and the efficiency of the legal system, are a fundamental cause of civil war. In particular, an improvement in institutions from the median value in the sample to the 75th percentile is associated with a reduction of 38 percentage points in the incidence of civil wars. Moreover, once institutions are included as explaining civil wars, income does not have any effect on civil war, either directly or indirectly. ${ }^{69}$

Or, to put it in more impenetrable and compelling form:

$$
\begin{aligned}
& \text { conflict }_{i 60-05}=\alpha+\beta_{1} \lg d p_{i 60}+\beta_{2} \text { lpop }_{i 60}+\beta a v_{-} i n s t+\mathcal{E}_{i} \\
& a v_{-}{ }_{i n s t} t_{i}=\delta 1 \text { col_orig }+\delta_{2} \ln \ln \text { mortal }+\omega_{i}
\end{aligned}
$$

Or, to put it more transparently: We have a feeling that whether or not you have a civil war depends on who colonised you, which determines your 'institutions', which we can't measure, so we are using numbers which we think reflect legal things, which we think reflect institutions. We will now press 'Enter'.

The absence of data makes this exercise ostensibly quantitative but essentially qualititative. Some key questions for the legally trained: Do you recognise law as

68 Morten Jerven speaking to Russ Roberts (Econtalk, 7 January 2013) < http://www.econtalk.org/archives/2013/01/jerven_on_measu.html>. Accessed March 22 2013. See also Morten Jerven, Poor Numbers: How we are mislead by African development statistics and what to do about it (Cornell University Press, 2013); Amanda Perry-Kessaris, 'Finding and facing facts about legal systems and FDI in South Asia' (2003) 23:4 Legal Studies 649.

69 Simeon Djankov and Marta Reynal-Querol, 'The Causes of Civil War' WPS4254 (World Bank 2007), 1. Emphasis added. 
represented in this paragraph? If not, are you nonetheless secretly convinced that something significant has been found? ). 'Institutions' are more than 'protection of property rights, rule of law and the efficiency of the legal system', and they are determined by more than one-off 'colonial origins'. More generally, 'poverty' is more than the absence of 'income'; and association, it is always worth reiterating, is not causation (there may be no link, a reverse link or a separate cause affecting both variables). And what of the only really pressing question: how to pop up to that magic $75^{\text {th }}$ percentile, with the associated gain of 38 percentage points less civil war? There is nothing to see here.

A welcome contrast is provided by Abhijit Banerjee and Esther Duflo-two academicpractitioner economists who are relatively in touch with their inner sociologist. In a passage that would have socio-legal scholars (and legal comparitivists) nodding enthusiastically, they note that the 'INSTITUTIONS' upon which economists and political scientists lavish most of their attention, such as property rights and democracy, are 'realised, on the ground, through many specific local institutions.' For example, property rights 'are constituted by a wide range of laws—about who can own what...,what ownership means..., how the combination of the legal system and the police acts to enforce those laws..., and much more.' So to properly 'understand the effect of institutions on the poor what is needed is a shift in perspectives from INSTITUTIONS in capital letters to institutions in lower case-“the view from below."'70 Banerjee and Duflo emphasise that the implicit movement away from the 'big questions' and 'big answers' beloved of academics and policy makers does not constitute a scaling back of aspirations for, or commitment to, improving human wellbeing. ${ }^{71}$ It is, they contend, simply more effective to approach development through lives of real people. If all of this sounds too expensive, no problem: empirical research is likely to be less costly than illconceived legal reform, so all we need to do is sit tight until we can afford to the research.

$70 \quad$ Abhijit V. Banerjee and Esther Duflo, Poor Economics: Barefoot hedge-fund managers, DIY doctors and the surprising truth about life on less than $\$ 1$ a day (Penguin 2010), 243. 


\section{Normative approach}

The normative characteristics of an approach are found in the values and interests that it foregrounds or privileges. Sociology is, in the words of Roger Cotterrell, fundamentally concerned with 'seeking similarity' and 'appreciating difference'.72 Likewise, Zelizer sees her work as a historian-dubbed-economic-sociologist 'partly as rescue operation' to assist those who are interested in the econo-socio (including legal) to 'recognize similar forms of interpersonal negotiation and cultural accumulation in a wide range of settings, whether or not they belong to the traditional subject matter of economics' ${ }^{73}$ She sees contemporary economic sociology as building a hopeful space thanks both to its emphasis on difference ('the variable quality, intensity, meaning, and consequences of relational ties among economic actors'); and its search for similarity in unexpected places (beyond 'firms and markets' and onwards to, for example, 'households, informal economies...microcredits, migrant remittances'). ${ }^{74}$

There remains disagreement among sociologists as to whether action should be taken to prioritise certain values and interests over others. In this respect it can be distinguished from mainstream economics, which has long pretended to be value-free. At the minimum, an economic sociology of law must identify the values and interests present in all levels, forms and types of (econo-legal) social life; as well as the relationships between them. For example, in this era of 'public-private partnerships' and 'third sectors', development encounters often involve three sets of actors: private, state and civil society. Research into development processes often focuses on the perspective of one of these sets of actors, resulting in 'a patchy collection of parallel accounts, which do

72 Roger Cotterrell, 'Seeking similarity, appreciating difference: comparative law and communities' in Andrew Harding and Esin Örücü (eds), Comparative Law in the 21st Century (Kluwer Law International 2002).

73 Ibid, p. 10. See Fred Block, 'Relational work and the law: Recapturing the Legal Realist critique of market fundamentalism' in Diamond Ashiagbor, Prabha Kotiswaran and Amanda Perry-Kessaris (eds) Towards an Economic Sociology of Law (WileyBlackwell 2013).

$74 \quad$ Vivianna A. Zelizer, Economic Lives: how culture shapes the economy (Princeton University Press 2011), 6. 
little to build upon or influence each other.' Economic sociology of law offers the missing 'integrated analysis of the interests, values and legal needs' of all three sets actors.'75 The very practical significance of this normative approach is visible in a recently completed case study of the wind energy sector in Cyprus where an integrated account of the values and interests that are at stake in legal development has facilitated a number of significant new insights. Until this year Cyprus has been categorised under the Kyoto Protocol as a developing country whose wind farms can produce carbon credits under the Clean Development Mechanism. Interviews and secondary materials revealed that competing rationalities dominate the two relevant legal regimes (economic rationalism and administrative rationalism in the case of the Kyoto carbon emissions regime, and democratic pragmatism and administrative rationalism in the case of the Aarhus participation regime); furthermore there were fundamental mismatches between the worlds envisaged by the regimes' creators, and real-life interactions among developers, engineers, regulators, project-affected persons and civil society actors in Cyprus. Crucially, those mismatches were sometimes to the benefit of developers, project-affected persons and/or government actors, and sometimes to their detriment; but never to the clear benefit of the electricity consumers of Cyprus or the many millions affected by climate change globally. ${ }^{76}$

\section{Coda}

This article began with the observation that Law and Development is in a mess and economic sociology of law might help to tidy it up. Yet econo-socio-legal approaches are themselves ostensibly messy. And this is how it should be. As Edelman and Stryker, leading proponents of sociological approaches to econo-legal life, point out, 'by introducing the legal and cultural construction of preferences and the social embeddedness of economic action' sociologically informed approaches are 'necessarily ... less elegant' than economic approaches. True: while economic answers may be 'clear',

75 Amanda Perry-Kessaris, Global Business, Local Law: The Indian legal system as a communal resource in foreign investment relations (Ashgate 2008), 4-5.

76 Amanda Perry-Kessaris, 'Anemos-ity, apatheia, enthousiasmos: An economic sociology of law and wind farm development in Cyprus' 40:1 Journal of Law and Society 2013 Special Issue on Towards an Economic Sociology of Law 68-91. 
sociological answers may be 'murky' or not 'definitive'. However, 'what is lost in parsimony will be gained in accuracy because life—even economic life-is complex'. ${ }^{77}$

\section{Connection through visualisation}

'Work for life and not for palaces, temples, cemeteries, and museums. Work in the midst of everyone, for everyone, and with everyone.'

Aleksandr Rodchenko, $1921^{78}$

If it is to be widely applicable, open to challenge and therefore, robust, an econo-sociolegal approach to development must be communicable across disciplines, as well as between academic, practitioner and public audiences. 'Law and development' is a fundamentally interdisciplinary field of thinking and practice, so it is difficult to communicate clearly and engagingly. It is also a field of great economic and political significance, about which the public both want to know, and can teach researchers, much. So it is important to communicate it clearly and engagingly.

Even if one were to accept that economic sociology is beautiful and useful, and might get legal development out of its present pickle, how best to communicate it? 'It is difficult enough', wrote painter Paul Klee, to 'arrive at a conception of a whole which is constructed from parts belonging to different dimensions'-and 'still more difficult to help another to such a comprehensive view.' This is especially true when we restrict ourselves to 'conveying' such a view using the inherently 'consecutive' and 'temporal' medium of the 'spoken word'.79 How often, and how soon, do we glaze over during the definitional stage of a presentation? Writing things down can help, because it allows us to flit forwards and backwards through a series of words. But it is easier to begin to make sense of multidimensional communications when they are presented succinctlyon one, actual or notional, page.

The requisite level clarity and directness can be achieved through visual rhetoric. It is commonly reported that we remember just 10 percent of what we hear and 20 percent

77 Lauren B. Edelman and Robin Stryker, 'A Sociological Approach to Law and the Economy' in Neil J. Smelser and Richard Swedberg (eds)The Handbook of Economic Sociology (Princeton University Press 2005), 528.

78 Quoted in Ellen Armstrong (ed), Graphic Design Theory: readings from the field (Princeton Architectural Press 2009), 24. 
of what we read, but 80 percent of what we see and do; and that over 80 percent of the information we absorb is visual. ${ }^{80}$ So it is unsurprising that rule makers and breakers have long used graphic methods to communicate legal developments: ${ }^{11}$ from the pillars of the Emperor Ashoka (240 BCE), ${ }^{82}$ to the posters used by settlers to explain the Rule of Law to the indigenous peoples of Australia (1800s), ${ }^{83}$ to the defacement of coins by Suffragettes (early 1900s), ${ }^{84}$ to contemporary diagrams appearing in the publications of the World Bank. 85

There is plenty of space for visual material, whether two or three dimensional, moving or still; to be created by or for researchers, with a view to engaging with academic, policy and public audiences. ${ }^{86}$ With mild regrets to Morris, this would be a documentary, rather than aesthetic, project. For, as artist Malcolm Hughes observed: 'When you talk about aesthetic it's as though arrows are pointing inwards into the [image] you are discussing. When you talk about the documentary, the descriptive, the arrows are going outwards into the social world.' 87 Graphic design is of particular interest in this context,

$80 \quad$ Jerome Bruner, Actual Minds, Possible Worlds (Harvard University Press 1987).

81 See also Peter Goodrich, Legal Emblems and the Art of Law: Obiter depicta as the Vision of Governance (Cambridge 2014).

82 Neil MacGregor, A History of the World in 100 Objects (Viking Books 2011), Chapter 32.

83 Desmond Manderson, "The Law of the Image and the Image of the Law: Colonial Representations of the Rule of Law' (2012-2013) 57 N.Y.L. Sch. L. Rev. 153, 156.

84 Neil MacGregor, A History of the World in 100 Objects (Viking Books 2011), Chapter 95.

85 For a critique of one example see the forthcoming entry by Kerry Rittich on the Thinking into|about Practice Project at http://www.kent.ac.uk/law/tiap.

86 For an invaluable and critical introduction to visual methodologies see Gillian

Rose Visual Methodologies (2013 Sage Publications). See for example the Visual Rhetoric project of the London College of Communication and the London School of Economics in which social scientists are matched with graphic designers to produce visualisations: http://www2.lse.ac.uk/intranet/LSEServices/TLC/whatWeDo/visualRhetoric.aspx.

$87 \quad$ Malcolm Hughes quoted in Elizabeth Chaplin, Sociology and Visual Representation (Routledge 1994), 197. 
for while ambiguity and multiplicity are welcomed in other disciplines within the fine arts, in design they are traditionally seen as signs of failure. A central purpose of graphic design is to communicate a uniform message to diverse audiences, so it has huge potential to generate interest and debate, reduce confusion and highlight gaps and conflicts; at every stage of the research process (conceptualisation, data collection, analysis, dissemination); not least in an interdisciplinary, cross-cultural and contentious field such as 'law and development'. 88

Graphic design is rich and diverse field, of which it is only possible to give a hint in a publication of this size and non-visual orientation. So the following paragraphs give a touch on just two aspects of graphic design: typography and information design. Graphics are presented throughout this paper as experimental gestures towards the communicative potential of a visualized economic sociology of legal development.

\section{Typography}

In an iconic 1930 lecture, typographer Beatrice Warde declared it to be 'sheer magic' to 'be able to hold a one-sided conversation by means of black marks on paper with an unknown person halfway across the world.' She spoke of written and verbal communication as 'quite literally forms of thought transference', arguing that 'it is this ability and eagerness to transfer and receive the contents of the mind that is almost alone responsible for human civilization.' ${ }^{89}$

In some cases lettering and type are the message. So, for example, in Figure 3 solid modular lettering is manoeuvred to express the idea that neither law itself, nor perspectives on law, is solid, impermeable or unchanging (Figure XX). Law may create a shadowy world of knock on effects, it may work in exactly the opposite direction to that intended, it may be hollow and useless, it may misfire, and it may dissemble entirely.

$88 \quad$ However, as in many other disciplines, the 'cultural turn' has seen a widening call for designers to acknowledge the roles played by (multiple) human perception(s). See Abbot Miller and Ellen Lupton, Design Writing Research: writing on graphic design (Phaidon 1999), 62

89 Beatrice Warde, 'The Crystal Goblet: or why printing should be invisible'. Lecture delivered to the British Typographers' Guild at the St Bride Institute on October $7^{\text {th }}$, 1930. Quoted in Ellen Armstrong (ed), Graphic Design Theory: readings from the field (Princeton Architectural Press 2009) 40. 
[Figure 3 about here]

Likewise, in Figure 4, multiple typefaces are used to communicate the bringing together of four distinctive empirical, normative and analytical approaches into one economic sociology of law and development. The starting letter of each discipline is set in a typeface that evokes the character of the discipline: (E)conomics in Wim Crouwel's modular, geometric New Alphabet (1967); (S)ociology in Eric Gill's open, humanist 'Gill Sans' (1928); (L)aw in John Baskerville's eponymous aspirational yet traditional serif (1757), and (D)evelopment in Robert Middleton's rough and ready Stencil (1938). In the final section, the disciplines resolve into a fairly harmonious inter-disciplinarity, using variations from a single family: Martin Majoor's (1990-1993) FFScala and FFScala Sans.

[Figure 4 about here]

In other cases, the designer's mission is to render typography invisible. Indeed Beatrice Warde herself charged typographers to create 'crystal goblets': vessels through which to transfer unencumbered the messages of which they are custodian. This is the design ethos that commonly underlies information design.

\section{Information design}

Information design includes everything from instruction manuals, to maps and signage, to quantitative data visualisation tools. ${ }^{90} \mathrm{~A}$ central objective of information design is to reduce levels of 'information anxiety', which is 'produced by the ever-widening gap between what we understand and what we think we should understand'.91 Information design is intended to convert data into usable material. Data are 'raw...symbols or isolated and non-interpreted facts', available in ever-increasing amounts to all humans, including socio legal scholars. Data become useful when they have been transformedthrough interpretation-into information. ${ }^{92}$ The full potential of that information is realized when it is transformed onwards to knowledge and, at the end of the

\footnotetext{
90 See for example the work of Hans Rosling at http://Gapminder.org.

91 Richard Saul Wurman, Information Anxiety (Doubleday 1989), cover page.

92 Sigmar-Olaf Tergan and Tanja Keller, Knowledge and Information Visualization: Searching for Synergies (Springer 2005), 3.
} 
'understanding spectrum', wisdom.93 Richard Saul Wurman famously proposed that, while 'information may be infinite', there are only five methods by which to 'structure' it so that it can begin to be transformed into knowledge: category (for example by function or colour), time, location, alphabet, or continuum (such as largest to smallest, least to most expensive). The trick is to choose the method (and the specific variation thereof) that is most suited to the 'story you want to tell'—or, rather, the knowledge you wish to transmit. ${ }^{94}$

Good information design gives to 'viewers' the 'control of information,' so that they may 'select...narrate, recast and personalize data for their own uses'. Such a transfer of power is consistent with the 'operating moral premise of information design', which 'should be that our readers are alert and caring'. ${ }^{95}$ So to approach the econo-socio-legal in this visual way need not be to reduce it to its lowest common denominators. It ought to be to render it accessible, through hard work-work that is performed on the, morally appropriate, sending side of a communicative relationship. Visualising social life requires perilous translations and compromises, and enthusiastically bad design results in timewasting, distortionary 'chartjunk'. Such pitfalls are best avoided through collaboration with experts, or specialist training—both of which avenues are as timeconsuming and expensive as they are rewarding. ${ }^{96}$ Perhaps for that reason, examples of information design aimed at communicating the substance of law are rather rare. ${ }^{97}$ The use of visual communication represents a complete break with conventional legal thinking and practice, which is overwhelmingly text-based and pays little attention to communication per se. One example of the deep embedding of information design in

93 Nathan Shedroff 'Information interaction design: a unified field theory of design' in R. Jacobsen (ed.) Information Design (MIT Press 1999) 270-1.

$94 \quad$ Richard Saul Wurman, Information Anxiety (Doubleday 1989), 59.

$95 \quad$ Edward Tufte, Envisioning Information (Graphics Press 1990) 50 and 34.

96 For examples see my blog Approaching the econo-socio-legal: an academic chronicle at http://econosociolegal.blogspot.com.

97 Visual Law: what lawyers need to learn from information designers. Voxpopulii Blog 13 May 2013. http://blog.law.cornell.edu/voxpop/2013/05/15/visual-law-whatlawyers-need-to-learn-from-information-designers/ 
legal communications is the work of Vikalp Design. ${ }^{98}$ This group, lead by designer Lakshmi Murthy, co-creates communications materials with and for illiterate and lowliterate rural communities in the Indian states of Rajasthan and Gujarat. Specifically, they ensure that end users create the images used in the materials. They have used this method to, among other things, create accessible explanations of the structure and operation of the Panchayati Raj system of local government. ${ }^{99}$ A second example comes from New York City, where the Centre for Urban Pedagogy issues an annual call for civil society groups to propose a 'complex policy issue' which needs to be explained to a 'particular constituency'. The winning issue is the subject of a 'collaborative design process', resulting in an engaging and accessible guide for distribution to 'people who need to know, people who want to know and people who like design'. Recent designs have covered the rights of street vendors and of domestic workers. ${ }^{100}$ Other examples include the Creative Commons icons, ${ }^{101}$ the UK Government's Good Law campaign ${ }^{102}$ and Legal Design Jams, in which graphic designers and law students have come together to visualize legal materials ranging from Microsoft Online Store terms and conditions to the United Nations Convention on Contracts for the International Sale of Goods. ${ }^{103}$ Rarer still are examples of information design that seek to communicate the nature of legal (let alone econo-socio-legal) concepts and even research processes. But there are certainly sources by which to be inspired. A reliable starting point is Gillian Rose, who has systematically explored the use of photographs as a research tool to, among other things, elicit and document research findings. ${ }^{104}$ Meanwhile, self-styled 'information journalist' David McCandless has done much to raise the profile of visualization as a tool

$98 \quad$ See http://www.vikalpdesign.com.

99 Codesign, 'For the people. By the people' in Dekho: Conversations on design in India (Codesign 2012), 80-101. Available at http://www.codesign.in 100 http://welcometocup.org/Projects/MakingPolicyPublic. See also http://cs.anu.edu.au/people/Michael.Curtotti/papers/visualizationfinal.pdf.

101 See http://creativecommons.org/licenses.

102 See https://www.gov.uk/good-law.

103 See http://legaldesignjam.com.

104 See also Johanes Wheeldon and Mauri Åhlberg, Visualising Social Science Research (Sage Publications 2012). 
for widening understanding. One of his more effective works, Left v. Right, created with designer Stefanie Posavec, illustrates the opposing approaches of left and right wing political parties to society, culture and economy. As McCandless has emphasized, in order to make this balanced visual it was necessary for him not just to acknowledge, but to give shape to, concepts and values in direct opposition to his own. Their absence or diminution in a textual piece might pass un-, or at least less-, noticed. ${ }^{105}$ Finally, Figure 5 shows an extract from a map-typology-timeline-guidebook created for a tour of 'legal treasure' at the British Museum. ${ }^{106}$ Here the design is intended to draw the viewer into a more measured, contemplative approach, so that they might begin to treasure the econo-socio-legal.

[Figure 5 about here]

Visualisation is not essential to the success of econo-socio-legal research, and graphic design is not the only avenue by which visual literacy might be exploited. ${ }^{107}$ But the time

105 David Macandless TED Talk 16:28 referring to the drafting of Left v Right in David Macandless, Information is Beautiful (Collins 2010) 14-15.

106 For more on Legal Treasure Tours see http://www.kent.ac.uk/law/ltt To see the full guide see http://cargocollective.com/AmandaPerryKessaris/Legal-TreasureGuide.

107 See for example David Lewis, Dennis Rodgers and Michael Woolcock (eds), Popular Representations of Development: Insights from novels, films, television and social media (Routledge 2014). There is much to be learned from the use of mobile apps to encourage and enable the communication of social data, such as levels of happiness, from subjects to researchers: See for example http://www.trackyourhappiness.org and http://www.mappiness.org.uk both accessed on March 22 2013. See also Agent-Based Social Simulation (ABSS), the purpose of which is to use quantitative and qualitative research to build models of individualised responses of multiple actors to changes in their environment (physical, regulatory and so on) and thereby to communicate those responses in a way that is accessible to the researcher: Casanovas Pompeu, Sartor Giovanni, Casellas Núria, Rubino Rossella (Eds.) Computable Models of the Law (Springer-Verlag 2008); Nigel Gilbert and Klaus G. Troitzsch Simulation for the Social Scientist (Open University 2005); and a presentation by Bruce Edmonds at http://www.methods.manchester.ac.uk/methods/abss/accessed on March 222013. Thanks to Clare Williams for introducing me to world of ABSS. 
to attract graphic designers to a project such as the visualization of an economic sociology of law is perhaps riper now than it has ever been. March 2014 saw the publication of the third 'First Things First' manifesto, the first of which was issued in 1963/4 and the second in 2000. All three manifestos called for designers to refocus away from commercial advertising work and towards more 'worthy' projects. The 1963 wish list of 'worthy' projects includes scientific and industrial publications. The 2000 version emphasises the need to address 'unprecedented environmental, social and cultural crises'. In 2014 it is 'education, medicine, privacy and digital security, public awareness and social campaigns, journalism, information design, and humanitarian aid' that are worthy, and designers are invited to 'transform our systems of finance and commerce, and reinforce human rights and civil liberties.' The need to use design at every stage of the social scientific research process is implicit in all three calls. ${ }^{108}$

\section{Conclusion}

'Law and development', this gift that keeps on giving, cannot proceed on its current narrow path. As billions of dollars of national and international resources are diverted towards law and development activities working together, in parallel and in opposition to each other, and away from other potentially productive uses, so grows the intellectual and practical need for Sen's 'interconnections', Tamahana's 'connectedness' and Zelizer's 'connected lives'. The absence of a shared analytical framework-a set of concepts and relationships through which to describe and evaluate the role of law in improving human welfare-is especially significant. Clearly articulated concepts and relationships are essential to the robustness of any social scientific endeavour. They promote (empirical) transparency in the collection and interpretation of data, and (normative) transparency in respect of any underlying values and interests. Scholars and practitioners working within a widely accepted analytical framework find their skills and discoveries become transferable and can be relied upon by others who need no longer reinvent the wheel. Transparency and transferability are especially important

108 The original First Things First Manifesto was drafted by Ken Garland and delivered at the Institute of Contemporary Arts in 1963: http://kengarland.co.uk/KGpublished-writing/first-things-first. The first renewal, First Things First 2000, was published in 1999 by Adbusters, Eye Magazine, Emigre, and others: http://www.eyemagazine.com/feature/article/first-things-first-manifesto-2000. First Things First 2014 was initiated by Cole Peters and is available at http://firstthingsfirst2014.org. 
in the context of a 'comprehensive' approach to development, which demands that development work be inter-disciplinary, drawing on all forms of empirical data and serving the full spectrum of normative (values and interests) biases. Most of all, approaches to law and development need not be uniform; but they ought to take note of, place themselves in relation to, and build upon, each other.

Economic sociology is distinguished by a unique motivation, and capacity, to connect multiple social levels and perspectives. It offers a connected picture of the econo-legal as social phenomena, and the related roles of law to support multiple patterns and types of social (including economic) life. What if this picture could be communicated using an integrated visual vocabulary (set of images, symbols and annotations) to denote the substantive, analytical, empirical and normative elements of an econo-socio-legal approach to development; and if visual techniques could be applied to attract, inform and empower academics, practitioners and lay people at every stage of 'law and development' thinking and practice? Such a visualised economic sociology of legal development might be both useful and beautiful.

All of this aspirational talk must be set in the wider context of the more fundamental message shared by Morris and Tamanaha: if in doubt, don't. Indeed, a key finding of an economic sociology of law and development programming and institutions might well be that they have no right to be saved. To this Tamanaha would add the comfort that nothing would be lost in the process: were all 'law and development' projects 'to ceaseimmediately', legal development would not. Legal institutions, and 'legal actors' would continue to use, abuse and avoid law— to 'interact with' — to 'push and prod' — the legal system. Some of the same kinds of projects might be pursued, but following 'local agendas and priorities'. They might not be successful, but they would not suffer from 'key flaws that now plague law and development projects' per se. ${ }^{109}$ More often than not, it seems that the most practical contribution to be made by those who have resources to the legal development of those who do not, is to think more about thinking about it. But an academic would say that.

109 Brian Z. Tamanaha, 'The primacy of society and the failures of law and development' [2011] 44 Cornell International Law Journal 209, 241. 
Figure 1: Three-to-one: approaching the econo-socio-legal

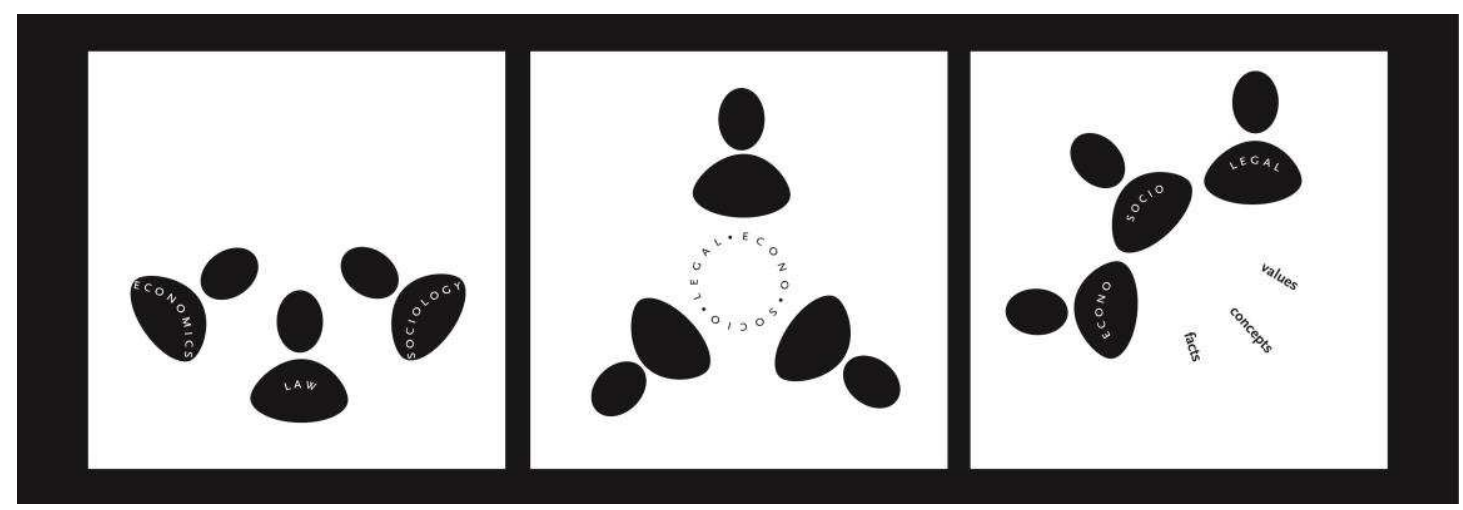

Designer and (C) Amanda Perry-Kessaris.

Figure 2: Connected lives

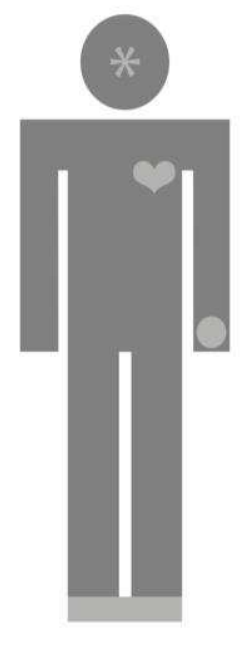

Belief

Affective
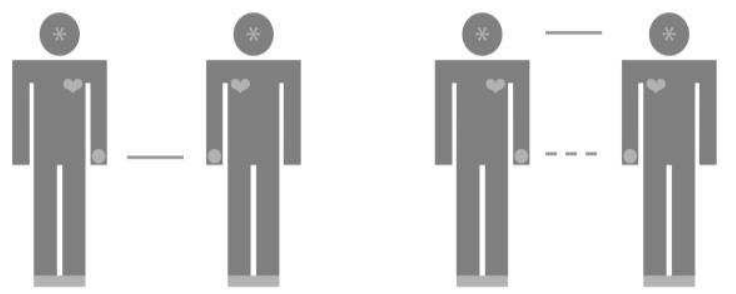

Traditional
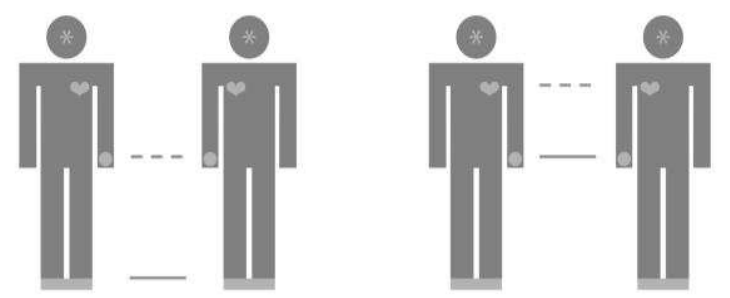

Designer and (C) Amanda Perry-Kessaris.

Figure 3: Laws

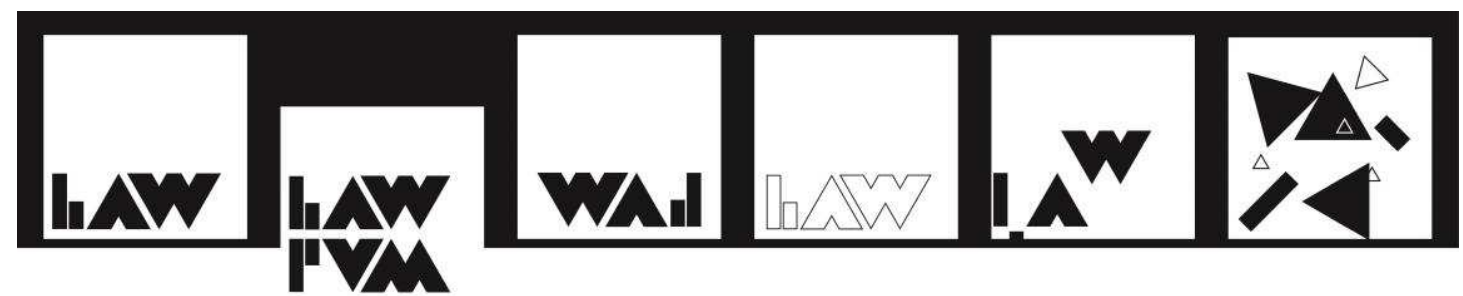

Designer and (C) Amanda Perry-Kessaris 
Figure 4: Economic Sociology of Legal Development

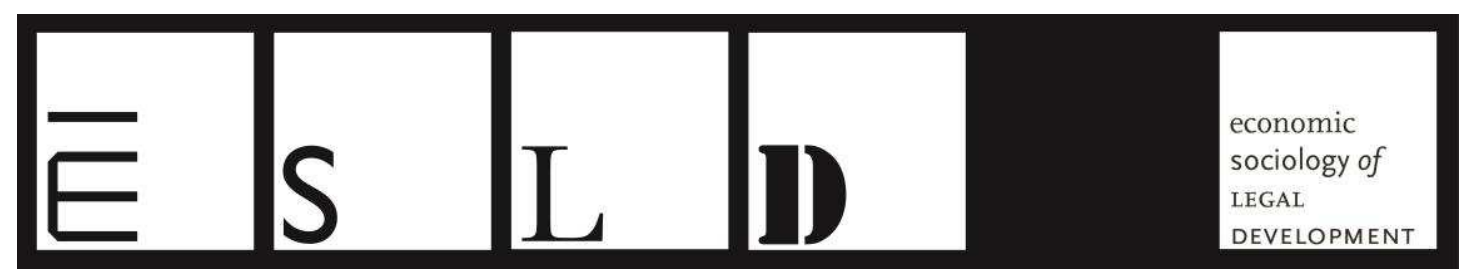

Design and (C) Amanda Perry-Kessaris

Figure 5: Legal treasure tour extract

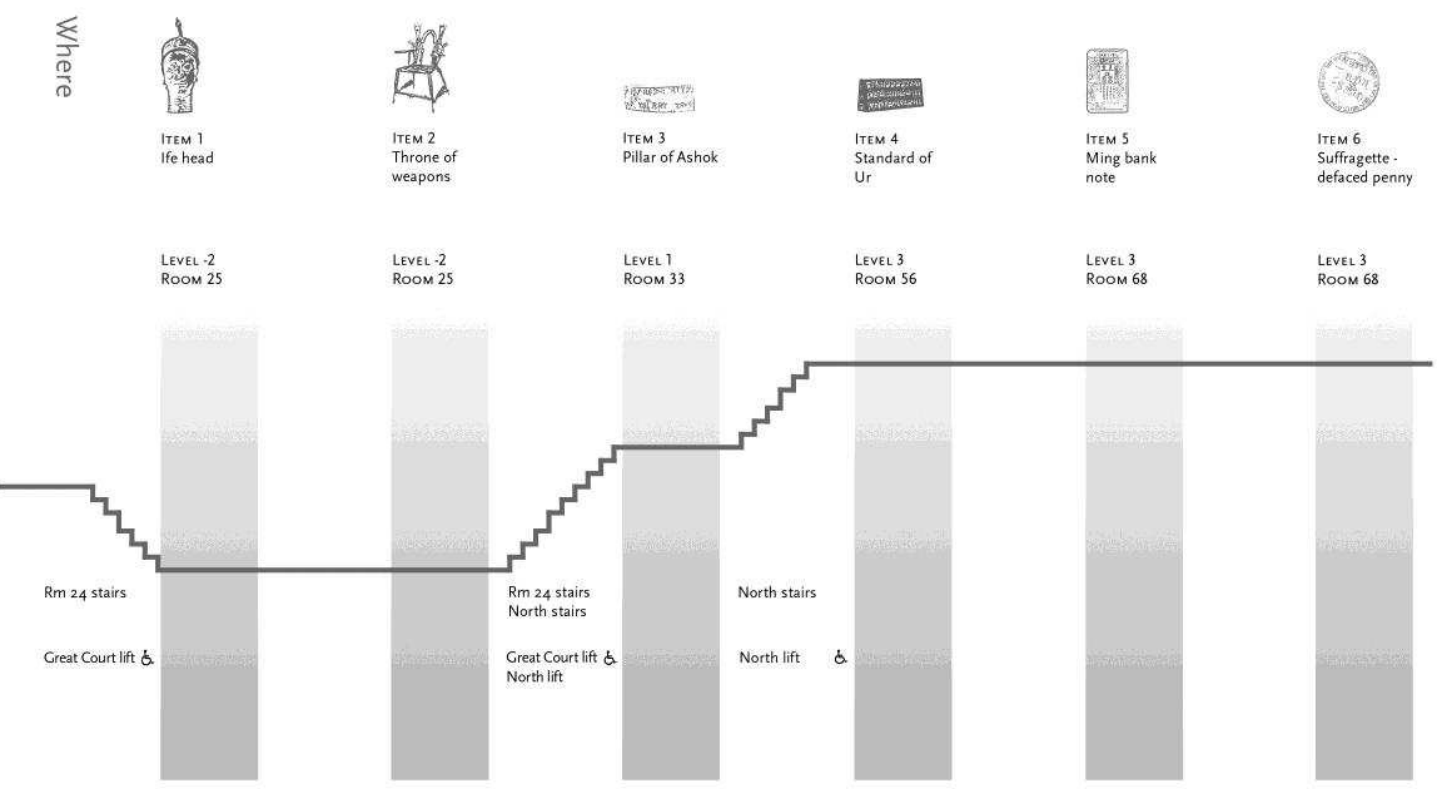

Designer and (C) Amanda Perry-Kessaris 